\title{
PERENCANAAN PARTISIPATIF DALAM PEMBANGUNAN DAERAH
}

\author{
PARTICIPATORY PLANNING IN LOCAL DEVELOPMENT
}

Aryati Puspasari Abady

Program Studi Ilmu Administrasi Publik Pasca Sarjana Universitas 45 Makassar Jl. Urip Sumoharjo Km 4 , Makassar 90231 Telp : 0411-452901

\section{ABSTRACT}

Planning is done by the current government is a plan that has been implemented by using the mechanisms of the Regional Planning Council (Musrenbang) both at the village, district, county / city and provincial level. Implementation plan based on community participation is based on Law No. 25 Year 2004 on National Development Planning System. Implementation Musrenbang conducted so far by the government still needs to search and study further. This relates to whether the processes are carried out only to be a legitimacy for the government to formulate a policy so that it becomes a justification that the policies established through a participatory process or mechanism of development policy formulation planning had been aspirational. Policies established through a participatory process has a high acceptability if implemented. This is because all stakeholders are involved in every stage of policy development planning.

Keywords: Planning, Participatory Local Development

\begin{abstract}
ABSTRAK
Perencanaan yang dilakukan oleh pemerintah saat ini merupakan perencanaan yang telah dijalankan dengan menggunakan mekanisme Musyawarah Perencanaan Pembangunan Daerah (Musrenbang) baik di tingkat kelurahan, kecamatan, kabupaten/kota maupun di tingkat provinsi. Implementasi perencanaan yang berbasis pada partisipasi masyarakat didasarkan pada Undang-undang Nomor 25 Tahun 2004 tentang Sistem Perencanaan Pembangunan Nasional. Pelaksanaan Musrenbang yang dilakukan selama ini oleh pemerintah masih perlu penelusuran dan kajian lebih lanjut. Hal ini berkaitan dengan apakah proses yang dilakukan hanya menjadi sebuah legitimasi bagi pemerintah dalam menyusun kebijakan sehingga menjadi sebuah pembenaran bahwa kebijakan yang ditetapkan tersebut melalui proses yang partisipatif atau mekanisme perencanaan penyusunan kebijakan pembangunan memang sudah aspiratif. Kebijakan yang ditetapkan melalui proses yang partisipatif memiliki akseptabilitas tinggi jika diimplementasikan. Hal ini disebabkan karena semua stake holder merasa ikut dilibatkan dalam setiap tahapan penyusunan kebijakan perencanaan pembangunan daerah.
\end{abstract}

Kata kunci: Perencanaan, Partisipatif, Pembangunan Daerah. 


\section{A. PENDAHULUAN}

Kebijakan otonomi daerah dengan konsep sistem pemerintahan desentralisasi memberikan ruang kepada warga masyarakat untuk ikut berpartisipasi dan mengambil peran yang lebih besar dalam merumuskan kebijakankebijakan daerahnya, (Kurniawan, 2007; 79). Dalam hal ini ada empat hal yang dapat dimanfaatkan seluas-luasnya oleh warga dengan kebijakan otonomi daerah dan sistem pemerintahan desentralistis. Pertama, partisipasi warga dalam pembuatan kebijakan dapat memperkuat konsolidasi demokrasi. Kedua, warga dapat berpartisipasi dalam menciptakan pemerintahan yang efektif dan efisien. Ketiga, warga akan dengan mudah menyalurkan aspirasinya dan berperan dalam merumuskan berbagai pembuatan kebijakan. Keempat, akan meningkatkan pembagian hasil dari sumberdaya alam dan kekayaan yang dimiliki daerah.

Partisipasi masyarakat menjadi salah satu jargon yang telah mengemuka saat ini pemerintahan yang baik (good governance). Dengan demikian proses pemerintahan yang dijalankan atas dasar partisipasi masyarakat telah memiliki salah satu karakteristik sebagai pemerintahan yang baik, (Hosnan, 2007:36). Keberadaan partisipasi masyarakat menurut Budiarjo dalam Hosnan (2007) pada dasarnya tidak terlepas dari pertimbangan bahwa kedaulatan ada di tangan rakyat yang melaksanakannya melalui kegiatan bersama untuk menetapkan tujuan serta masa depan masyarakat itu dan untuk menentukan orang-orang yang akan memegang tampuk pimpinan untuk masa berikutnya. Bahkan lebih jauh Bintoro Tjokroamidjojo (2004) mengatakan bahwa pembangunan yang meliputi segala segi kehidupan, politik, ekonomi, dan sosial budaya itu baru akan berhasil apabila merupakan kegiatan yang melibatkan partisipasi dari kegiatan seluruh rakyat di dalam suatu negara.

Adanya partisipasi masyarakat merupakan salah satu faktor dari keberhasilan otonomi daerah. Masyarakat daerah, baik sebagai kesatuan sistem maupun sebagai individu, merupakan bagian integral yang sangat penting dari sistem pemerintahan daerah, karena secara prinsip penyelenggaraan otonomi daerah ditujukan guna mewujudkan masyarakat sejahtera di daerah yang bersangkutan, (Kaho, 2003: 120).

Perencanaan partisipatif yang dilaksanakan oleh pemerintah daerah mengacu pada regulasi yang telah ditetapkan oleh pemerintah pusat. Perencanaan pembangunan dengan pelibatan masyarakat dilakukan dengan mekanisme musrenbang mulai dari tingkat kelurahan hingga di tingkat provinsi. Penyelenggaraan Musrenbang khususnya untuk penyusunan.

Rencana Kerja Pemerintah Daerah (RKPD) dilakukan setiap tahun menjadi suatu hal yang cukup menarik karena kegiatan ini menjadi sebuah agenda rutin yang dijalankan oleh pemerintah daerah pada tahapan perencanaan pembangunan dengan pelibatan masyarakat. Teknis pelaksanaan kegiatan tersebut mengacu pada Surat Edaran Bersama oleh Kepala Bappenas dan Mendagri Nomor 0008/ M.PPN/01/2007 dan 050/264A/SJ tentang Petunjuk Teknis Penyelenggaraan Musrenbang.

Pelibatan Masyarakat pada kegiatan Musrenbang dalam rangka penyusunan RKPD yang selama ini dilaksanakan cenderung hanya menjadi sebuah justifikasi terhadap sebuah proses perencanaan pembangunan daerah. Pemerintah memang memberikan ruang bagi masyarakat untuk ikut berpartisipasi dalam proses perencanaan, namun pada tahapan penetapan program/kegiatan yang akan ditetapkan sebagai kebijakan terkadang tidak mengakomodir usulan yang berasal dari kebutuhan masyarakat. Ruang yang diberikan oleh pemerintah kepada masyarakat hanya sekedar untuk memenuhi ketentuan regulasi yang tercantum dalam Undang-udang Nomor 25 Tahun 2004 yang mensyaratkan bahwa mekanisme perencanaan pembangunan tetap memprioritaskan keterlibatan masyarakat secara luas. Hal ini juga sesuai dengan laporan hasil penelitian yang dilakukan oleh Bahagijo dan Triwibowo (2008) dari Perkumpulan Prakarsa yang melakukan penelitian terhadap dominasi elite lokal dalam reformasi kebijakan pro-poor di Kota Makassar dan Kota Kendari. Penelitian ini menemukan bahwa jalur partisipatif terpinggirkan dalam arena dominan. 
Kajian ini menemukan bahwa meskipun jalur politis, jalur teknokratis/birokratis dan jalur partisipatif bekerja dalam arena perencanaan dan penganggaran, namun jalur teknokratis dan politis terlihat lebih dominan.

Hasil penelitian tersebut menunjukkan bahwa terjadi diskoneksi antara proses Musrenbang dengan proses alokasi anggaran. Output perencanaan yang dibawa ke dalam arena penganggaran lebih didominasi oleh output perencanaan teknokratis oleh Walikota, Bappeda dan SKPD. Di sisi lain, mekanisme penjaringan aspirasi masyarakat (Jaring Asmara) atau Musrenbang pada arena penganggaran juga tidak berjalan efektif. Menurut penelitian tersebut, di Makassar justru menunjukkan bahwa mekanisme musrenbang lebih dimanfaatkan sebagai politik citra dengan strategi untuk mengukur derajat respon masyarakat, aspirasi dan orientasi politik semata. Ada kecendurungan mekanisme Musrenbang tidak menjadi bagian strategis yang bakal terumuskan dalam program pembangunan maupun dianggarkan.

Hasil penelitian Bahagijo dan Triwibowo (2008) menegaskan bahwa keterlibatan masyarakat nampaknya hanya sebatas pada proses pengusulan program maupun kegiatan pembangunan melalui LPM pada setiap kegiatan Musyawarah Perencanaan Pembangunan baik di tingkat kelurahan dan kecamatan maupun di tingkat kota. Pada saat pemerintah menyusun dokumen perencanaan yang berisi program/kegiatan prioritas, masyarakat tidak dilibatkan sama sekali. Kondisi ini yang menyebabkan dokumen perencanaan yang dihasilkan oleh pemerintah daerah cenderung akomodatif.

Dalam penyelenggaraan kegiatan Musrenbang yang dilakukan setiap tahun oleh pemerintah, mulai dari tingkat kelurahan dan kecamatan hingga pada penyelenggaraan Musrenbang di tingkat kota memperlihatkan kecenderungan tingkat partisipasi masyarakat yang masih rendah. Hal ini terjadi pada pelaksanaan musrenbang setiap tahunnya. Tingkat pertisipasi masyarakat dalam pelaksanaan Musrenbang yang masih rendah juga diutarakan oleh lurah maupun camat sebagai fasilitator penyelenggaraan Musrenbang.
Dari hasil penelusuran yang dilakukan, diketahui pula tingkat kehadiran masyarakat dalam penyelenggaraan musrenbang kelurahan dan kecamatan dari tahun ke tahun masih di bawah angka 50 persen dari undangan yang diedarkan oleh pihak penyelenggara (pemerintah dan LPM). Hal tersebut di atas juga diakui oleh kepala Bappeda Kota Makassar dari hasil wawancara oleh media dan dipublikasi di internet yang menyatakan bahwa minat masyarakat Makassar mengikuti Musrenbang masih rendah. Hal ini berdasarkan hasil penelitian dari sejumlah lembaga pemantau yang ada di daerah ini. Laporan pemantau independen mencatat bahwa hanya sekitar 40 persen partisipasi masyarakat dalam mengikuti kegiatan Musrenbang. Justru yang hadir hanya pejabat grass rood (Ketua RT dan RW) dan Lembaga Pemberdayaan Masyarakat (LPM).

\section{B. PERENCANAAN PASRTISIPATIF DALAM PERSPEKTIF ADMINISTRASI PUBLIK}

Perencanaan partisipatif merupakan salah satu proses pembelajaran yang penting bagi masyarakat. Perencanaan partisipatif adalah perencanaan yang dalam tujuannya melibatkan kepentingan masyarakat, dan dalam prosesnya melibatkan masyarakat baik langsung maupun tidak langsung. Perencanaan partisipatif artinya menekankan partisipasi luas dari semua stakeholders dalam proses perencanaan dan pengambilan keputusan dalam pembangunan, (Suratman, 2008)

Konsep pembangunan partisipatif dikemukakan oleh Nasrun (2008) yaitu pembangunan yang dilaksanakan oleh berbagai komponen kepublikan (pemerintah, swasta dan organisasi masyarakat non pemerintah) secara tersistem. Selanjutnya dinyatakan bahwa ketertarikan sistemik dari berbagai komponen kepublikan dalam pembangunan daerah memerlukan langkah penyusunan portofolio yang didahului proses evaluasi internal dengan menggunakan analisis SWOT.

Perencanaan partisipatif menurut Abe (2008:81) adalah perencanaan yang dalam tujuannya melibatkan masyarakat, dan dalam prosesnya melibatkan masyarakat (baik 
secara langsung maupun tidak langsung). Abe juga menawarkan dua bentuk perencanaan partisipatif yaitu: pertama, perencanaan yang langsung disusun bersama rakyat, berupa perencanaan lokasi setempat (menyangkut daerah di mana masyarakat berada) dan berupa perencanaan wilayah yang disusun dengan melibatkan masyarakat secara perwakilan; kedua, perencanaan yang disusun melalui mekanisme perwakilan sesuai institusi yang sah (seperti parlemen).

Esensi pembangunan partisipatif adalah pembangunan yang dilaksanakan dengan mengoptimalkan pelaksanaan fungsi-fungsi manajemen; pembangunan yang mengaktualkan perilaku kepublikan (transparansi, konsistensi, akuntabilitas dan kepastian hukum); pembangunan yang berorientasi pada peningkatan kemandirian, kredibilitas, kemitraan dan keunggulan (K4). Conyers (1991:154155) menjelaskan tiga alasan utama mengapa partisipasi masyarakat penting dalam proses pembangunan, yaitu: (1) partisipasi masyarakat dapat menjadi "telinga" untuk memperoleh informasi mengenai kondisi, permasalahan dan kebutuhan masyarakat; (2) efektifitas dan efesiensi dari program atau proyek pembangunan akan lebih mudah dicapai, apalagi dalam kondisi kontribusi masyarakat dapat mengurangi beban biaya yang harus dikeluarkan untuk suatu implementasi pembangunan; dan (3) partisipasi secara etik-moral merupakan hak demokrasi bagi rakyat, sehingga dengan partisipasi yang maksimal pemerintah sudah otomatis meredam potensi resistensi dan proses sosial bagi efek-efek samping pembangunan.

Partisipasi sebagai nilai dasar demokrasi menjadi perhatian penting dalam administrasi publik yang demoktratis. Pada dasarnya, gagasan partisipasi dalam administrasi publik mencakup dua ranah, yaitu manajemen partisipatif dan partisipasi masyarakat dalam administrasi publik. Osborne \& Gaebler (2005) mengungkapkannya ketika memasukkan dua prinsip yang menyentuh dua ranah tersebut dalam prinsip-prinsip reinventing government. Pertama, prinsip "community owned government: empowering rather than serving" yang menunjukkan betapa pentingnya partisipasi masyarakat dalam administrasi publik. Kedua, prinsip "decentralized government: from hierarchy to participation and teamwork" yang menunjukkan betapa pentingnya manajemen partisipatif yang memungkinkan partisipasi dalam penyelenggaraan administrasi publik.

Wamsley \& Wolf (1996) mengumpulkan berbagai tulisan yang melukiskan betapa pentingnya melibatkan masyarakat dalam administrasi publik pada posisi sebagai warga negara bukan sekedar sebagai pelanggan. Dalam bukunya menekankan betapa pentingnya democratic government yang mengedepankan partisipasi masyarakat dalam administrasi publik. Little (1996, dalam Warmsley \& Wolf 1996) menjelaskan konsepsi democratic public administration dengan memaparkan konsekuensi tiga substansi demokrasi. Government of the people berarti pemerintahan masyarakat akan membawa legitimasi bagi administrasi publik. Government by the people berarti menjamin adanya representasi administrator publik dan akuntabilitas administrasi publik terhadap masyarakat. Government for the people berarti bahwa administrasi publik akan benar-benar menjalankan kepentingan publik, bukan kepentingan birokrasi.

Gagasan administrasi publik demokratis juga diungkapkan oleh Denhardt \& Denhardt (2007) dengan adanya perspektif new public service yang menunjukkan betapa pentingnya partisipasi masyarakat ini dalam administrasi publik. Arnstein (1971) mengemukakan teori yang cukup terkenal yaitu ladder of participation (tangga partisipasi). Teori ini mengemukakan bahwa partisipasi sebagai bentuk kekuasaan masyarakat yang dapat mempengaruhi perubahan pembuatan kebijakan. Arnstein mengklasifikasikan derajat partisipasi dalam tiga kategori yang dirinci ke dalam delapan anak tangga partisipasi. Derajat terendah adalah non partisipasi. Partisipasi yang terjadi pada level ini adalah aktifitas partisipasi semu atau terjadi distorsi partisipasi. Derajat kedua memperlihatkan adanya patisipasi (tokenism). Derajat ini lebih membuka ruang untuk dilakukan dialog publik sehingga warga memiliki kesempatan untuk 
menyampaikan aspirasi maupun pendapatnya, namun pada derajat ini masyarakat belum terlihat langsung dalam pengambilan kebijakan. Derajat ketiga adalah kendali warga. Pada tingkatan ini, masyarakat memiliki akses yang lebih besar dan keterlibatan secara langsung, baik pada proses pembuatan kebijakan hingga pada tahap implementasi kebijakan oleh pemerintah. Pada derajat ini terjadi redistribusi kekuasaan dari pemerintah kepada masyarakat melalui negosiasi. Burns, Hambleton dan Hogget kemudian mengem-bangkan teori partisipasi publik yang lebih besar sesuai dengan analisis pemerintahan daerah. Teori tersebut dinamakan "ladder of citizen empowerment" (tangga pemberdayaan masyarakat).

Beberapa pemikiran yang melatarbelakangi teori yang dikemukakan tersebut. Pertama, konsep yang dikemukakan oleh Hirschman pada tahun 1970 dimana strategi pemberdayaan terdiri atas dua pilihan, yaitu exit dan voice. Kedua, pemikiran yang melatarbelakangi adalah pembedaan antara konsep pilihan, partisipasi dan kendali. Pemikiran ketiga adalah ruang lingkup kekuasaan warga. Partisipasi warga dalam ruang lingkup kekuasaan pemerintahan daerah dibedakan dalam tiga wilayah pengambilan keputusan, yaitu praktek operasional, keputusan anggaran, dan pembuatan kebijakan.

Analisis yang dilakukan Burns, Hambleton dan Hogget dengan berdasarkan pada beberapa pemikiran yang melatarbelakangi teori ladder of citizen empowerment maka diperoleh tiga derajat partisipasi masyarakat dan dua belas anak tangga. Masing-masing derajat partisipasi dibagi dalam beberapa anak tangga yang jaraknya tidak sama pada masing-masing derajat. Berkaitan dengan partisipasi masyarakat, tidak terlepas dari Teori Pilihan Publik (Public Choice). Denhardt and Denhardt (2007) menjelaskan salah satu ide dari new public service adalah seek the public interest dimana administrator publik harus memberikan sumbangsih untuk membangun kepentingan publik bersama. Tujuannya tidak untuk menemukan solusi cepat yang diarahkan oleh pilihan-pilihan perorangan tetapi menciptakan kepentingan bersama dan tanggungjawab bersama.
Pilihan publik didasarkan pada rational choice theory, (Frederickson \& Smith, 2003). Cendekiawan yang menjadi pioneer terhadap rational choice ini adalah Adam Smith. Menurutnya bahwa orang-orang yang melakukan pencarian terhadap kepentingan diri mereka, melalui mekanisme "invisible hand", menghasilkan secara kolektif manfaat yang menguntungkan bagi semua masyarakat.

Menurut Nugroho (2003), model kebijakan pilihan publik merupakan proses formulasi keputusan kolektif dari individu-individu yang berkepentingan ataskeputusan tersebut. Pada intinya, setiap kebijakan publik yang dibuat oleh pemerintah harus merupakan pilihan dari publik yang menjadi pengguna (beneficiaries atau customer dalam konsep bisnis). Proses formulasi kebijakan publik dengan demikian melibatkan publik melalui kelompok-kelompok kepentingan. Secara umum, ini adalah konsep formulasi kebijakan publik yang paling demokratis karena memberi ruang yang luas kepada publik untuk mengkontribusikan pilihan-pilihannya kepada pemerintah sebelum diambil keputusan.

Model Kerangka Konseptual perencanaan partisipatif dalam konteks pembangunan daerah dituangkan dalam gambar skema seperti dibawah ini:

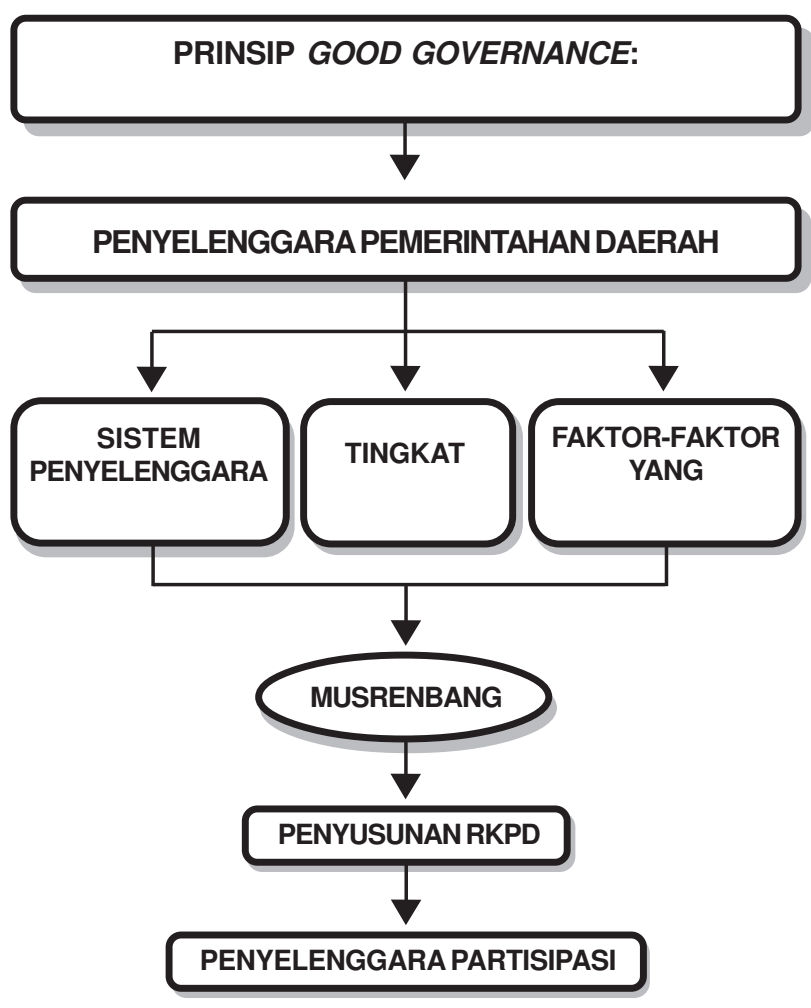




\section{SISTEM PERENCANAAN PEMBANGUNAN DAERAH YANG PARTISIPATIF}

Award (1979:3 dalam Amirin, 1989:10) menjelaskan bahwa sistem merupakan sehimpunan komponen atau sub sistem yang terorganisasikan dan berkaitan sesuai dengan rencana untuk mencapai sesuatu tujuan tertentu. Berkaitan dengan hal tersebut, maka dalam sistem perencanaan pembangunan dibutuhkan berbagai masukan, proses maupun keluaran yang merupakan sub sistem yang akan menjadi satu sistem yang saling berkaitan dengan tujuan untuk penyusunan dokumen perencanaan yang baik.

Musyawarah perencanaan pembangunan daerah yang dilaksanakan, baik untuk program/kegiatan yang akan dilaksanakan untuk jangka panjang, jangka menengah maupun rencana jangka pendek seharusnya dilakukan dengan mengutamakan partisipasi masyarakat sebagai wujud bottom-up planning. Hal ini dilakukan dengan melibatkan semua termasuk berbagai stakeholder terkait dengan mekanisme perencanaan pembangunan.

Perencanaan yang dibuat oleh masyarakat diawali dengan membuat daftar kebutuhan masyarakat dan merupakan masukan (input) dalam proses perencanaan untuk menjadi sebuah dokumen perencanaan yang mencerminkan keterlibatan masyarakat secara luas. Masukan yang dibuat oleh masyarakat didasarkan pada berbagai permasalahan yang timbul dalam masyarakat untuk kemudian dijadikan sebagai program maupun kegiatan yang butuh penanganan sebagai solusi dalam menyelesaikan masalah yang ada di masyarakat.

Penyusunan daftar kebutuhan masyarakat belum melibatkan semua elemen masyarakat. Kenyataan yang ditemui di lapangan diketahui bahwa daftar kebutuhan yang dibuat oleh masyarakat melalui ketua RT dan RW yang merupakan daftar inventarisasi sebagai hasil identifikasi yang dilakukan sendiri oleh para ketua RT dan RW dan tidak melalui proses Pra Musrenbang Kelurahan. Hal ini terjadi karena persepsi bahwa masyarakat sudah terwakili aspirasinya melalui para ketua RT dan RW.
Penyusunan daftar program dan kegiatan prioritas dibuat berdasarkan indikator standar sesuai dengan yang dipahami oleh masyarakat secara umum. Kaitannya dengan indikator penentuan program dan kegiatan prioritas yang akan dijadikan acuan oleh masyarakat, diketahui bahwa Bappeda sebagai penanggungjawab pelaksana kegiatan Musrenbang masih kurang melakukan sosialisasi terhadap indikator skala prioritas standar yang dapat dijadikan acuan oleh masyarakat. Tidak bisa dipungkiri bahwa indikator prioritas tersebut sangat membantu masyarakat untuk dapat mengidentifikasi program dan kegiatan yang dianggap prioritas. Dengan demikian, masyarakat memiliki perspektif yang sama untuk memahami program dan kegiatan yang prioritas dilaksanakan oleh Pemerintah.

Hal yang cukup menarik dan sering terjadi daftar prioritas program dan kegiatan yang telah dibuat sesuai dengan urutan prioritas. Namun saat ada kepentingan dari penentu kebijakan, baik yang berasal dari elite eksekutif maupun yang berada di legislatif, dengan sendirinya daftar prioritas yang telah dibuat akan mengalami perubahan urutan prioritas. Intervensi politik memiliki pengaruh yang besar terhadap bergesernya urutan skala prioritas karena besarnya kepentingan kelompok (interest group) terhadap pelaksanaan program atau kegiatan tersebut.

Program yang telah diidentifikasi berdasarkan berbagai indikator didanai melalui berbagai sumber pendanaan. Kegiatan yang didanai melalui APBD Kabupaten/Kota, APBD Provinsi serta APBN. Namun tidak sedikit usulan yang diharapkan oleh pemerintah dapat dilakukan melalui sharing. Berbagai bentuk pembiayaan yang telah disebutkan sebelumnya, juga dapat dibiayai melalui bantuan dalam bentuk hibah dari berbagai lembaga donor baik yang berasal dari dalam negeri maupun lembaga yang berasal dari luar negeri.

Model sharing pembiayaan program dan kegiatan cukup penting untuk didorong untuk direspon dan diberikan apresiasi. Hal ini disebabkan karena inti partisipasi adalah untuk menggugah masyarakat agar lebih memiliki tanggungjawab bersama-sama 
pemerintah dalam mengatasi persoalan yang ada di masyarakat. Dengan model sharing tersebut, masyarakat juga akan memiliki tanggungjawab moril (sense of belonging) untuk bisa memelihara hasil yang telah dibangun secara bersama-sama. Dengan demikian, program dan kegiatan yang menjadi prioritas oleh masyarakat dapat dilaksanakan sesuai dengan yang diharapkan.

Program dan kegiatan prioritas yang diusulkan masyarakat dan dianggap perlu mendapat perhatian serius dari pemerintah justru sering tidak diakomodir dalam dokumen perencanaan. Langkah yang sering dilakukan, baik oleh masyarakat maupun pemerintah adalah dengan membangun komunikasi secara informal dengan orangorang yang memiliki kewenangan dalam pengambilan kebijakan melalui invisible hand sehingga bisa membantu untuk merealisasikan kebutuhan masyarakat. Komunikasi yang dibangun secara informal tersebut ternyata menunjukkan hasil yang lebih optimal dan efektif dalam memperjuangkan program dan kegiatan prioritas untuk diakomodir dalam dokumen perencanaan serta dituangkan dalam pembiayaan melalui APBD.

Inovasi lain yang dilakukan adalah mencoba menggugah kepedulian para pengusaha yang melakukan aktifitas usaha di wilayah bersangkutan untuk berpartisipasi membangun masyarakat yang berada di sekitarnya. Langkah yang dilakukan oleh masyarakat bersama-sama pemerintah setempat dengan mengajukan proposal kepada para pengusaha sebagai bentuk pertanggung-jawaban sosial pengusaha dalam bentuk Corporate Social Responsibility (CSR) kepada masyarakat sekitarnya. Selain itu, langkah yang biasa dilakukan adalah dengan mencoba melakukan pendekatan dengan pihak pemerintah yang lebih di atas termasuk dengan pemerintah pusat dan lembaga donor dengan tujuan agar bisa dilakukan penyelarasan program dan kegiatan yang akan dilaksanakan dengan usulan yang dimiliki oleh masyarakat.

\section{TINGKAT PARTISIPASI MASYARAKAT DALAM PENYELENGGARAAN MUSRENBANG}

Pelaksanaan Musrenbang membuka ruang kemitraan kepada pemerintah kelurahan dan kecamatan bersama-sama dengan Lembaga Pemberdayaan Masyarakat. Kemitraan yang dilakukan atas pembagian tanggungjawab dan kewenangan pelaksanaan kegiatan Musrenbang ternyata tidak sepenuhnya dilaksanakan. Realitas yang masih terjadi yaitu penanggungjawab sekaligus pelaksana kegiatan Musrenbang dilakukan oleh pemerintah kelurahan dan kecamatan. Hal ini yang menjadi salah satu pemicu terjadinya disharmonisasi hubungan antara lurah dan camat dengan pengurus LPM.

Bappeda sebagai leading sector pelaksanaan kegiatan Musrenbang dan penyusunan RKPD belum bisa menyediakan informasi yang memadai mengenai hasil pelaksanaan kegiatan Musrenbang tingkat kabupaten/ kota. Informasi tersebut terkait dengan program ataupun kegiatan prioritas yang terakomodir dalam dokumen perencanaan yang belum efektif disosialisasikan kepada masyarakat. Dengan demikian, kredibilitas Bappeda bisa meningkatkan kepercayaan masyarakat, bukan hanya proses perencanaan yang dilakukan secara partisipatif , tetapi hasil dari proses panjang dan melibatkan masyarakat juga bisa dipertanggungjawabkan.

Tingkat kehadiran masyarakat pada penyelenggaraan Musrenbang kelurahan dan kecamatan masih menunjukkan tingkat kehadiran yang rendah. Tingkat kehadiran masyarakat dioengaruhi berbagai faktor, namun khusus bagi masyarakat perkotaan faktor yang paling dominan mempengaruhi tingkat kehadiran masyarakat adalah rutinitas masyarakat yang tergolong cukup padat. Dengan demikian, masyarakat tidak memiliki waktu yang banyak untuk ikut terlibat langsung pada kegiatan Musrenbang.

Keterwakilan masyarakat, khususnya dalam penyelenggaraan Musrenbang Kelurahan belum sepenuhnya menghadirkan semua elemen masyarakat. Beberapa kelompok masyarakat belum terwakili termasuk masyarakat marginal, kelompok pendidik, maupun beberapa elemen lain yang ada di masyarakat. Temuan menarik khususnya keterwakilan masyarakat adalah pada saat penyusunan 
dokumen perencanaan hasil Musrenbang tingkat Kota, Bappeda tidak lagi mengikutsertakan masyarakat untuk ikut menentukan program dan kegiatan prioritas yang akan diakomodir dalam RKPD.

Derajat partisipapsi masyarakat pada kegiatan Musrenbang Kelurahan dan Kecamatan dikaitkan dengan derajat partisipasi masyarakat dari Burn, Hambleton dan Gogget diketahui berada pada derajat partisipasi warga (citizen participation). Namun setiap tahapan berbeda anak tangga derajat partisipasinya.

Semakin tinggi jenjang pelaksanaan Musrenbang, partisipasi masyarakat semakin rendah anak tangga partisipasinya. Dengan kata lain bahwa partisipasi masyarakat tinggi pada tahapan Musrenbang lebih awal (Kelurahan dan Kecamatan), namun semakin tinggi tingkatan pelaksanaan musrenbang (Kota dan Provinsi) partisipasi masyarakat justru semakin rendah karena ruang yang diberikan (public space) sudah berkurang.

\section{E. FAKTOR-FAKTOR YANG MENENTUKAN TINGKAT PARTISIPASI MASYARAKAT DALAM PENYELENGGARAAN MUSRENBANG}

\section{Komitmen Pemerintah}

Komitmen pemerintah dalam hal perencanaan partisipatif melalui penyelenggaraan Musrenbang belum dilaksanakan sepenuhnya. Hal ini dapat dilihat dari proses tahapan Musrenbang yang belum dijalankan dengan benar seperti proses Pra-Musrenbang padahal proses inilah yang sesungguhnya menjadi entrypoint bagi masyarakat secara umum untuk menyalurkan aspirasi dan kebutuhan mereka. Selain itu, pemerintah juga tidak melibatkan masyarakat dalam proses penentuan program dan kegiatan prioritas. Masyarakat hanya terlibat dalam bentuk pemberian usulan program sedangkan penetapan program dan kegiatan yang menjadi prioritas sebahagian besar bukan merupakan hasil usulan masyarakat.

Hal lain adalah program dan kegiatan yang telah ditetapkan tidak disampaikan kembali pada kecamatan atau kelurahan. Akibatnya, masyarakat semakin kehilangan informasi tentang usulan prioritas mereka yang disampaikan dalam proses Musrenbang. Kondisi ini menunjukkan bahwa komitmen pemerintah masih rendah dalam mewujudkan perencanaan partisipatif melalui penyelenggaraan Musrenbang.

Rendahnya komitmen pemerintah terhadap penyelenggaraan Musrenbang yang memicu sikap apatis masyarakat. Hal ini terkait dengan proses penyusunan program dan kegiatan prioritas yang belum transparan. Dengan demikian, masyarakat memiliki tingkat partisipasi yang rendah karena mereka menganggap bahwa penyelenggaraan Musrenbang belum bisa dijadikan media yang efektif untuk menyalurkan aspirasi serta mengusulkan program dan kegiatan yang prioritas dari masyarakat untuk ditangani oleh pemerintah.

\section{Komunikasi}

Besarnya pengaruh komunikasi secara informal terhadap penyusunan dokumen perencanaan yang mengakibatkan daya tarik Musrenbang kurang kuat untuk mewujudkan perencanaan partisipatif. Dengan kata lain, penentuan program dan kegiatan prioritas justru efektif dilakukan melalui komunikasi informal yang dilakukan secara "invisible hand" oleh masyarakat terhadap pemerintah maupun penentu kebijakan.

Dalam konteks perencanaan partisipatif melalui mekanisme Musrenbang, maka dalam rangka meningkatkan partisipasi masyarakat dalam penyelenggaraan Musrenbang pemerintah sudah seharusnya menjadikan Musrenbang sebagai satu-satunya media komu-nikasi bagi masyarakat untuk mengusulkan berbagai program prioritas. Komunikasi informal bisa dilakukan, namun tetap mengacu pada dokumen hasil Musrenbang yang telah dilakukan oleh masyarakat.

Dengan demikian, masyarakat akan memiliki motivasi untuk ikut berpartisipasi dalam penyelenggaraan Musrenbang karena dokumen perencanaan hasil pelaksanaannya dijadikan acuan oleh pemerintah dalam mengakomodir usulan masyarakat dalam dokumen perencanaan dan anggaran. 


\section{Tingkat Sosial Ekonomi Masyarakat}

Tingkat sosial ekonomi masyarakat memiliki pengaruh terhadap tingkat partisipasi masyarakat. Masyarakat yang memiliki tingkat sosial ekonomi yang lebih baik dan berada pada tingkat menengah ke atas memiliki partisipasi cenderung sedikit lebih rendah dalam kegiatan Musrenbang kelurahan dan kecamatan. Jika dibandingkan dengan partisipasi masyarakat yang memiliki tingkat sosial ekonomi menengah ke bawah yang memiliki tingkat partisipasi yang lebih baik.

Hal ini disebabkan karena masyarakat yang memiliki rutinitas yang cukup padat dengan berbagai kegiatan memiliki keterbatasan waktu untuk ikut serta secara aktif dalam kegiatan Musrenbang. Namun di sisi lain, mereka tidak menutup diri dan berpartisipasi dalam bentuk sumbangan pemikiran maupun media penghubung yang efektif dengan para pengambil kebijakan, karena mereka memiliki hubungan yang cukup erat dengan para elite yang ada di eksekutif maupun di legislatif. Sehingga golongan masyarakat tersebut berpartisipasi dalam perencanaan pembangunan namun dilakukan secara pasif karena tidak menghadiri secara langsung kegiatan Musrenbang yang dilaksanakan.

Dengan rutinitas yang cukup padat, menyebabkan masyarakat yang berasal dari latar belakang ekonomi menengah ke atas tidak memiliki waktu untuk berpartisipasi dalam penyelenggaraan Musrenbang. Selain karena alasan tersebut, masyarakat yang memiliki tingkat sosial ekonomi yang cukup mapan cenderung lebih individual karena mereka beranggapan bahwa hamper semua kebutuhannya dapat dipenuhi, baik oleh upaya mereka sendiri atau melalui hubungan yang baik dengan para penentu kebijakan yang ada di eksekutif maupun di legislatif tanpa harus berpartisipasi dalam kegiatan Musrenbang.

\section{E. KESIMPULAN}

Perencanaan partisipatif dalam pembangunan daerah dapat dilaksanakan pemerintah jika didukung dengan sistem perencanaan yang baik, dimana masukan dari masyarakat yang berasal dari hasil identifikasi permasa- lahan dan kebutuhan prioritas. Disalurkan dengan proses yang baik dan mengakomodasi berbagai kebutuhan semua elemen masyarakat. Daftar kebutuhan masyarakat dibuat berdasarkan analisa dan pertimbangan potensi wilayah masing-masing. Dengan demikian, format yang baku diberlakukan oleh pemerintah kota sebaiknya disinergikan dengan kearifan lokal dari masyarakat serta wilayahnya.

Pelaksanaan program dan kegiatan yang dibiayai dari berbagai sumber, baik berasal dari APBD Kabupaten/Kota, APBD Provinsi maupun APBN atau bahkan bantuan/hibah dari lembaga donor tidak menjadi masalah, namun tetap mengacu pada pemenuhan kebutuhan masyarakat. Banyak program dan kegiatan yang dilaksanakan oleh pemerintah merupakan program dan kegiatan reaktif dan masih sedikit program dan kegiatan yang bersifat proaktif terhadap berbagai permasalahan yang dihadapi oleh masyarakat. Dan sangat terbatas program dan kegiatan yang lahir dari pemerintah bersifat antisipatif terhadap berbagai permasalahan yang mungkin di masyarakat.

Derajat partisipasi masyarakat dalam mekanisme Musrenbang sudah berada pada derajat partisipasi warga (citizen participation). Namun terjadi perbedaan anak tangga pada setiap tahapan Musrenbang, semakin tinggi tingkatan pelaksanaan Musrenbang, semakin rendah derajat partisipasi masyarakat dalam pelaksanaan Musrenbang.

Berbagai faktor yang mempenagruhi terhadap tingkat partisipasi masyarakat dalam penyelenggaraan Musrenbang adalah: (1) komitmen pemerintah; (2) komunikasi; dan (3) tingkat sosial ekonomi masyarakat.

\section{DAFTAR PUSTAKA}

Abe, A. 2002. Perencanaan Daerah Partisipatif. Solo: Pondok Edukasi.

Arnstein, Sherry R. 1971. "Eight Rungs on the Ladder of Citizen Participation" in Edgar S. Cahn and Barry A. Passet. Citizen Participation: Effecting Community Change. New York: Praeger Publishers. 
Burns, Danny. Robin Hambleton and Paul Hogget. 1994. The Politics of Decentralization: Revitalizing Local Democracy. London: Macmillan.

Denhardt, Janet V. and Robert B. Denhardt. 2007. The New Public Service: Serving, not Steering (Expanded Edition). Armonk, New York: M.E. Sharpe.

Frederickson, H. George and Kevin B. Smith. 2003. The Public Administration Theory Primer. USA: Wesview Press.

Hosnan. 2007. Mendorong Partisipasi Masyarakat dalam Pembangunan Daerah. Jurnal Membangun Indonesia dari Daerah: Partisipasi Publik dan Politik Anggaran Daerah. Jakarta: JICA.

Kaho, Josef Riwu. 2003. Prospek Otonomi Daerah di Negara Kesatuan Republik Indonesia: Faktor-faktor yang Mem-pengaruhi Penyelenggaraan Otonomi Daerah. Cetakan III. Jakarta: Rajawali Pers.

Kurniawan, Apep Fajar. 2007. Otonomi Daerah: Menumbuhkan Partisipasi Warga dalam Pembuatan Kebijakan.
Jurnal Membangun Indonesia dari Daerah: Partisipasi Publik dan Politik Anggaran Daerah. Jakarta: JICA.

Nasrun, Mappa. 2008. Makalah: Pembangunan Partisipatif. Kriteria Kelayakan dan Normatif. Makassar.

Nugroho D, Riant. 2003. Reinventing Pembangunan. Menata Ulang Paradigma Pembagunan untuk Membangun Indonesia Baru dengan Keunggulan Global. Jakarta: Elex Media Komputindo.

Osborne, David \& Ted Gaebler. 2005. Mewirausahakan Birokrasi. Reinventing Government. Jakarta: PPM.

Tjokroamidjojo, Bintoro. 2004. Reformasi Nasional Penyelenggaraan Good Governance dan Perwujudan Masyarakat Madani. Jakarta: Lembaga Administrasi Negara.

Wamsley, Gary L. And James F. Wolf. 1996. Refounding democratic public administration: modern paradoxes, postmodern challenges. Thousand Oaks, California: Sage Publications. 